\title{
Synthesis and antiplasmodial assessment of nitazoxanide and analogs as new antimalarial candidates
}

\author{
Camila Irabuena ${ }^{1,2}$ - Laura Scarone ${ }^{1}$ - Guilherme Eduardo de Souza ${ }^{3}$ Anna Caroline Campos Aguiar ${ }^{3}$.

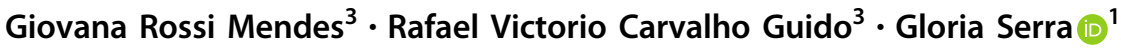

Received: 30 August 2021 / Accepted: 16 December 2021 / Published online: 28 January 2022

(c) The Author(s), under exclusive licence to Springer Science+Business Media, LLC, part of Springer Nature 2021

\begin{abstract}
During the last years, the progression to control malaria disease seems to be slowed and WHO (World Health Organization) reported a modeling analysis with the prediction of the increase in malaria morbidity and mortality in sub-Saharan Africa during the COVID-19 pandemic. A rapid way to the discovery of new drugs could be carried out by performing investigations to identify drugs based on repurposing of "old" drugs. The 5-nitrothiazole drug, Nitazoxanide was shown to be active against intestinal protozoa, human helminths, anaerobic bacteria, viruses, etc. In this work, Nitazoxanide and analogs were prepared using two methodologies and evaluated against $P$. falciparum 3D7. A bithiazole analog, showed attractive inhibitory activity with an $\mathrm{EC}_{50}$ value of $5.9 \mu \mathrm{M}$, low propensity to show toxic effect against HepG2 cells at $25 \mu \mathrm{M}$, and no cross-resistance with standard antimalarials.
\end{abstract}

Keywords Nitazoxanide $\cdot$ Analogues $\cdot$ Thiazoles $\cdot$ Malaria

\section{Introduction}

Malaria is caused by Plasmodium spp. parasites and transmitted to human by the Anopheles vector mosquito. The WHO 2020 report, estimated 229 million malaria cases in 2019, principally in the sub-Saharan region [1]. During the last years, the progression to control the disease seems to be slowed as the estimated deaths in 2019 were 409,000, compared with 405,000 deaths in 2018 and 585,000 in

Supplementary information The online version contains supplementary material available at https://doi.org/10.1007/s00044021-02843-1.

Rafael Victorio Carvalho Guido

rvcguido@usp.br

$\triangle$ Gloria Serra

gserra@fq.edu.uy

1 Química Farmacéutica, Departamento de Química Orgánica, Facultad de Química, Universidad de la República, General Flores 2124, CC1157 Montevideo, Uruguay

2 Graduate Program in Chemistry, Facultad de Química, Universidad de la República, Montevideo, Uruguay

3 São Carlos Institute of Physics, University of Sao Paulo, Avenida João Dagnone, 1100, São Carlos, São Paulo 13563-120, Brazil
2010, with $67 \%$ of infants under-five. The COVID-19 pandemic has impacted on the investigation and control of infectious diseases [2-4]. As a result of $75 \%$ reduction in routine malaria control measures, WHO (World Health Organization) reported a modeling analysis with the prediction of the increase in malaria morbidity and mortality in sub-Saharan Africa during the COVID-19 pandemic [5]. Moreover, the emergence of Anopheles vector resistance to the currently used insecticides and of malaria parasite resistance to the available drugs, including artemisinin and its derivatives [6-8], jeopardize malaria control achievements. Thus, there is an urgent need of new and safe drugs to treat this illness.

It is well known that drug discovery and development take about $12-15$ years and the process presents a substantial cost. However, an attractive and rapid way to the discovery of new drugs could be carried out by performing investigations to identify drugs to treat rare or common diseases based on repurposing of "old" drugs [9, 10]. Thiazole is an important class of five-membered heterocyclic compounds with diverse biological properties, thus it is found in many drugs such as sulfathiazol (antimicrobial drug), ritonavir (antiretroviral drug), abafungin (antifungal drug), and tiazofurin (antineoplastic drug) [11].

The 5-nitrothiazole drug, nitazoxanide (Ntz, 1 Fig. 1) presents various biological activities. Ntz was first 
Fig. 1 Antiplasmodial heterocycles: nitazoxanide (1), tizoxanide (2), thiazole derived amino acids (3), and aminomethylthiazole carboxamide derivatives (4)

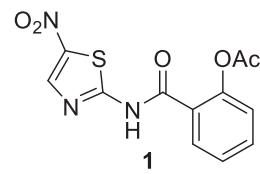

Nitazoxanide (Ntz)

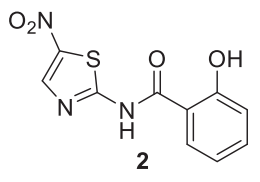

Tizoxanide (Tiz)

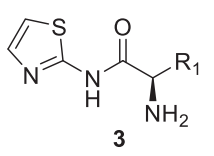

$\mathbf{R}_{1}$ : benzyl, indolyl

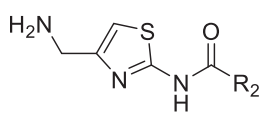

4

$\mathbf{R}_{\mathbf{2}}$ : phenyl, pirazole

\section{Ntz analogues}

as a veterinary anthelminthic agent. Then, this drug was shown to be active against intestinal protozoa, human helminths, and anaerobic bacteria [14-16]. In humans, Ntz is rapidly metabolized to tizoxanide (Tiz), which is as effective against these parasites and bacteria as the parent drug (Fig. 1). The initial indication for nitazoxanide was for cryptosporidiosis and giardiasis, but subsequent investigations have demonstrated that the drug is effective for amoebiasis [17]. In addition, Ntz is active against nonprotozoan parasites, including the intestinal tapeworm Hymenolepis nana [18], and Trichuris trichiura [19]. Moreover, many researchers concluded that it presents antiviral activity against enteric viruses, [20-22] MERS virus [23], and that $\mathrm{Ntz}$ and analogs are promising compounds to treat hepatitis $C$ infection [24-26]. Furthermore, several investigations were focused on the mechanisms of action [27-30].

During the last year, vast investigations to find drugs repositioning efficient against SARS-CoV2 were performed. As part of these studies, Ntz has demonstrated in vitro antiviral activity against SARS-CoV2 [30, 31]. In addition, it was suggested that this drug amplifies host innate immune antiviral responses by triggering foreign cytoplasmic RNA sensing and the type 1 interferon axis [32].

Navarrete-Vazquez et al. [33] synthesized two benzologues of Ntz and Tiz and compared their in vitro antiparasitic activities against Giardia intestinalis, Entamoeba histolytica, Trichomonas vaginalis, Trypanosoma cruzi, Leishmania mexicana and the rodent malaria parasite Plasmodium berghei. $\mathrm{Ntz}$ and Tiz showed $\mathrm{IC}_{50}$ values in the low micromolar range against $P$. berghei, $\left(\mathrm{IC}_{50} \mathrm{~s}\right.$ of $3.9 \mu \mathrm{M}$ and $5.2 \mu \mathrm{M}$, respectively). Furthermore, in a recent review, Sharma and Prashe highlighted several thiazole derived amino acids (3) [34], and aminomethylthiazole carboxamide derivatives (4) (Fig. 1) [35], as promising antimalarials with $\mathrm{EC}_{50}$ values in the low micromolar or submicromolar range, respectively [36]. Considering these results, we decided to explore the "old" and versatile drug Ntz, its metabolite Tiz and bis-heterocycles analogs as part of a research program for the synthesis of potential antimalarials [37-47].

In this work, we present the synthesis and the antiplasmodial activity of Ntz, Tiz, and 2-aminothiazole analogs (Fig. 2). These compounds and six 2-aminothiazole-4-carboylate

\section{Results and discussion}

\section{Analogs synthesis}

The synthesis was started with thiazole preparation from thiourea and bromoacetaldehyde diethyl acetal employing Hanstzch reaction to obtain compound 5, Scheme 1 [48]. Different ratios of $\mathrm{EtOH}$ and $\mathrm{AcOH}$ were assayed and the best yield was obtained with $\mathrm{AcOH} 100 \%$. Nitration using Dickey et al. methodology [49], resulted in compound 6 in good yield.

Aware of the low nucleophilicity of the aromatic amine of 2-aminothiazole [41, 47], and consequently, of the low or moderate yield for preparation of the corresponding amide, we paid special attention to the reported methodologies capable of performing this reaction.

Several groups reported the synthesis of Ntz analogs using acyl chloride derivatives; in other cases EDCI and $\mathrm{HOBt}$ or aminocarbonylation followed by iodobenzene substituted reaction were used. All of the methods reported moderate to good yields [50-53]. Recently, our group reported the successful use of oxyma (ethylcianoacetate oxime), in combination with DIC for solid phase peptide 
Scheme 1 Synthesis of $\mathrm{Ntz}$ and analogs of type A and B
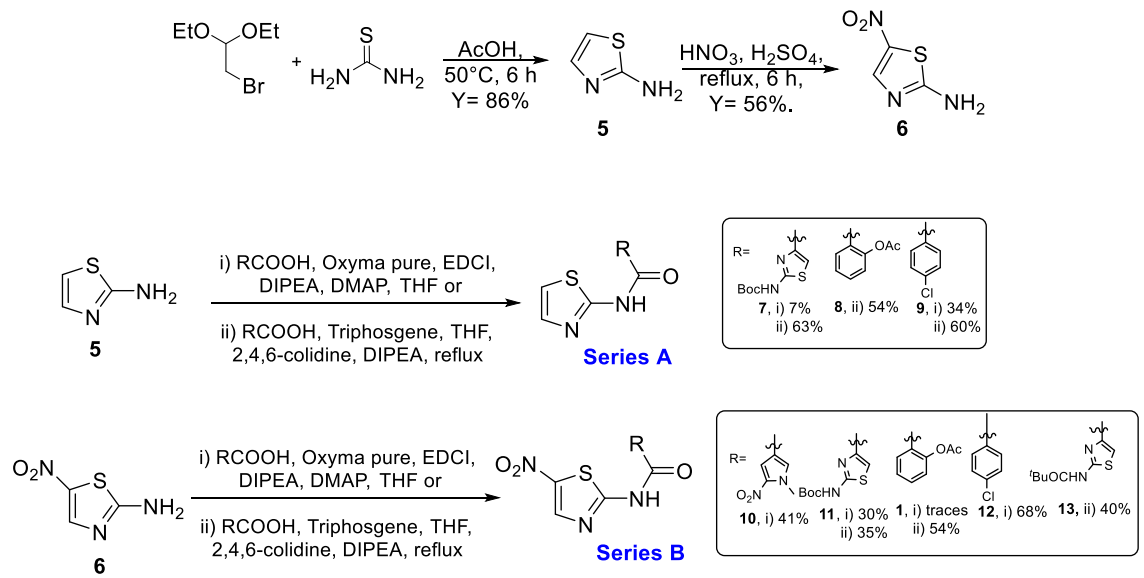

Scheme 2 Hydrolysis of the ester group of $\mathrm{Ntz}(\mathbf{1})$ and analog 8

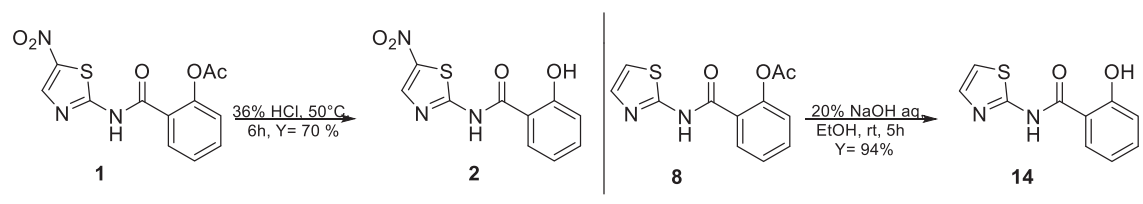

synthesis (SPPS) or with EDCI for solution macrocylization [54]. Moreover, Albericio et al. described the impressive coupling efficiency of this coupling agent surpassing HOAt in more demanding peptide models [55]. In addition, the in situ acyl chloride formation using triphosgene is a simple and effective methodology that allowed amide bond formation using aromatic amines [54]. Taking into account these previous results, we decided to explore the use of oxyma/EDCI or triphosgene to obtain amides from 2-aminothiazole compounds 5 or $\mathbf{6}$, Scheme 1 . The thiazole and pyrrole carboxylic acids used to obtain 7, 10, 11, and 13 were prepared as was described by our group [41].

Compounds 7 and 9 of A series, Scheme 1, were obtained using oxyma/EDCI in low or moderate yield, respectively. As analog $\mathbf{8}$ was obtained in a higher yield using triphosgene methodology, we explored this methodology for the synthesis of $\mathbf{7}$ and 9. Thus, using triphosgene, the yields for these amides derivatives were improved, from 7 to $63 \%$ for 7 and from 34 to $60 \%$ for $\mathbf{9}$. In the case of compounds of B series, Scheme 1, the use of oxyme allowed to obtain $\mathbf{1 0}$ and $\mathbf{1 2}$ in good (41\%) and very good yield (68\%), respectively, considering that $\mathbf{1 2}$ was obtained by Ballard and co-workers [53], using 4-chlorobenzoyl chloride in 57\%. It is important to note that in our case the reaction mixture of $\mathbf{1 2}$ was stirred for $4 \mathrm{~h}$ at reflux and then at room temperature for $24 \mathrm{~h}$.

Amides 11 and 1 were prepared by both strategies, (i) and (ii) Scheme 1. In the case of $\mathbf{1 1}$, the results were similar, but $\mathrm{Ntz}$ (1) was obtained only in traces from the reaction mixture using oxyma/EDCI. Nevertheless, the corresponding activated acetylsalycilic acid with oxyma was isolated and its structure was confirmed by NMR and MS analysis.

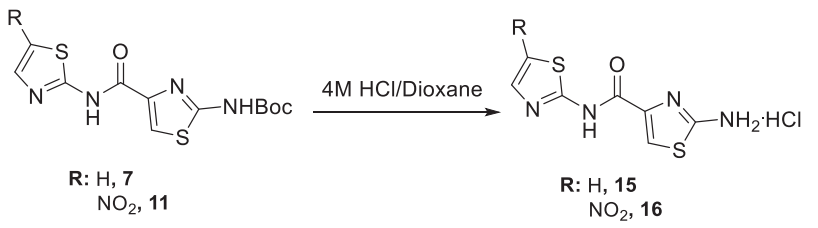

Scheme 3 Deprotection of compounds 7 and $\mathbf{1 1}$

In contrast, using triphosgene Ntz was obtained in 54\% yield. Taking into account these results, the strategy (ii) was selected to obtain compound $\mathbf{1 3}$ in $\mathbf{4 0 \%}$ yield based on the recovered starting material.

In order to obtain the Ntz metabolite, (2, Tiz), first, we tried hydrolysis using basic conditions, $20 \% \mathrm{NaOH} / \mathrm{EtOH}$ (1:1) or $20 \% \mathrm{LiOH} / \mathrm{EtOH}(1: 1)$, but instead of the desired compound, salicylic acid and acetylsalicylic acid were isolated from the reaction mixture. These results allowed us to conclude that in those conditions, the amide bond of $\mathbf{1}$ is labile. To overcome this difficulty, we intended acid conditions to hydrolyze 1 . Fortunately, the use of $\mathrm{HCl} 36 \%$ at $50{ }^{\circ} \mathrm{C}$ during $6 \mathrm{~h}$ rendered Tiz (2) in 70\% yield, Scheme 2. In the case of the Ntz analog (8), which does not present a nitro group, the hydrolysis was performed using basic conditions to obtain 14 in excellent yield (94\%).

In addition, two derivatives of $\mathbf{7}$ and $\mathbf{1 1}$ were prepared by deprotection of Boc with $\mathrm{HCl}(\mathrm{g}) /$ Dioxane to obtain $\mathbf{1 5}$ and 16, Scheme 3.

\section{Antimalarial evaluation}

The synthesized compounds and six analogs previously obtained by our group (17-22, Table 1) [41, 45, 47] were 
Table 1 Inhibitory activity average (\%) at $10 \mu \mathrm{M}$ against $P$. falciparum 3D7, chloroquine-sensitive

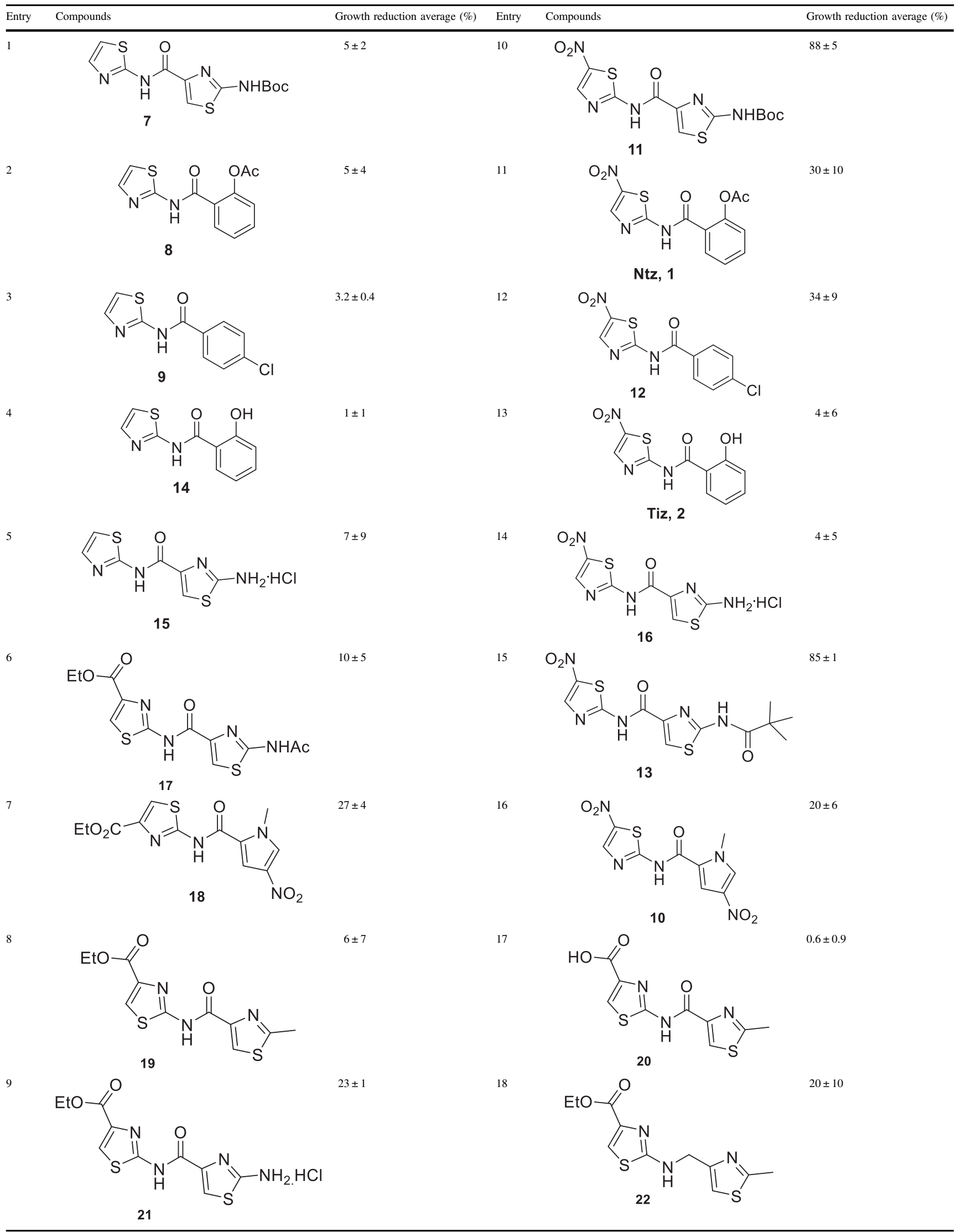


assayed at $10 \mu \mathrm{M}$ for inhibitory activity against the chloroquine-sensitive 3D7 strain of $P$. falciparum using the SYBR Green assay [56]. The inhibitory activities in Table 1 are the average values determined from two independent experiments.

The amides of 2-aminothiazole and the metabolite Tiz (2) showed poor inhibitory activity at $10 \mu \mathrm{M}$ (\% inhibition $<5 \%$ ). The same results were obtained for the derivatives of 2-aminothiazole-4-carboxylate, compounds 17, 19-22. However, some 5-nitro-2-aminothiazole derivatives (10-13) and compound 18 containing 1-methyl-4-nitropyrrole showed moderate growth inhibition of $P$. falciparum 3D7 at $10 \mu \mathrm{M}$ (\% inhibition $>27 \%$ ), suggesting that the presence of the $\mathrm{NO}_{2}$ substituent was favorable for inhibitory activity. Ntz (1) exhibited moderate activity against $P$. falciparum at $10 \mu \mathrm{M}$ (\% inhibition $=30 \%)$, whereas $\mathrm{Tiz}(2)$ was a poor inhibitor of $P$. falciparum 3D7 strain ( $\%$ inhibition $=4 \%$ ). By contrast, Ntz and Tiz showed $\mathrm{IC}_{50}$ values in the low micromolar range against $P$. berghei $(3.9$ and $5.2 \mu \mathrm{M}$, respectively) [33]. The parasites' susceptibility to Ntz and Tiz might be related to the genomic and proteomic differences between the $P$. falciparum (human malaria parasite) [57], and P. berghei (rodent parasite) [58], species. Indeed, a comparative analysis of the complete proteomes of primate- and rodent-Plasmodium species, including $P$. falciparum and $P$. berghei, identified 30 proteins well conserved in the primate parasites that are putatively absent in rodent parasites [59].

The Boc carbamate 11 and pivalic amide 13, exhibited greater inhibitory activity, $88 \%$ and $85 \%$ at $10 \mu \mathrm{M}$, respectively. In contrast, the amine derivative $\mathbf{1 6}$ showed decreased effect against $P$. falciparum 3D7 strain. Compounds 11 and 13 were tested in twofold serial dilutions, in two independent experiments. Table 2 displays the assessed
$\mathrm{EC}_{50}$ values for $\mathbf{1 1}, \mathbf{1 3}$, and artesunate, tested in parallel as a positive control. As both compounds $\mathbf{1 1}$ and $\mathbf{1 3}$ showed $\mathrm{EC}_{50}$ values in the low micromolar range, 5.9 and $8 \mu \mathrm{M}$, respectively, they were submitted to cytotoxic assessment against HepG2 cells (hepatocyte carcinoma) and the selectivity indexes (SI) were calculated. In the case of $\mathbf{1 1}$, the cytotoxicity determination was limited by the solubility of the compound under the assay conditions $(25 \mu \mathrm{M})$. By contrast, compound $\mathbf{1 3}$ had the cytotoxic effect assessed $\left(\mathrm{IC}_{50}=81 \mu \mathrm{M}\right)$, thereby allowing the determination of the SI. The SI value of 10 indicates a reasonable selectivity for the parasite cells (Table 2).

To further investigate the antiplasmodial activity of the nitazoxanide series, the cross-resistance profile of the representative nitazoxanide analog $\mathbf{1 1}$ was assessed against a panel of drug-resistant parasites (Table 3). The panel consisted of representative resistant strains including $\mathrm{Dd} 2$, TM90C6B, and $3 \mathrm{D} 7{ }^{\mathrm{R}}$ _848. Dd2 is a chloroquine-, cycloguanil-, and pyrimethamine-resistant strain, while the TM90C6B strain shows resistance against atovaquone. The $3 \mathrm{D} 7^{\mathrm{R}}$ _848 strain was generated in our laboratory and is resistant to MMV692848, a potent PfPI4K inhibitor. To verify the resistant profile of the selected strains, standard antimalarial drugs (artesunate, pyrimethamine, and atovaquone) and MMV692848 were assessed and used as positive controls for inhibition. The pyrimethamine, atovaquone, and MMV692848 showed greater $\mathrm{EC}_{50}$ values against the $\mathrm{Dd} 2, \mathrm{TM} 90 \mathrm{C} 6 \mathrm{~B}$, and $3 \mathrm{D} 7^{\mathrm{R}}$ _848 strains with resistance indexes $(\mathrm{RI})$ of $>222,>1250$, and 20 , respectively (Table 3). By contrast, the strains in the panel were sensitive to artesunate $\left(\mathrm{EC}_{50} \mathrm{~s}=7-12 \mathrm{nM}\right)$, confirming their susceptibility to inhibition by small molecules.

The inhibitory activity assessment of $\mathbf{1 1}$ against Dd2 and TM90C6B strains indicated that the $\mathrm{EC}_{50}$ values were three
Table 2 Half-maximal inhibitory concentration $\left(\mathrm{EC}_{50}\right)$ against $P$. falciparum 3D7, cytotoxicity against HepG2 and selectivity index

\begin{tabular}{|c|c|c|c|}
\hline Compound & $\begin{array}{l}\mathrm{EC}_{50}^{3 \mathrm{D} 7}(\mu \mathrm{M}) \\
\pm \mathrm{SD}\end{array}$ & $\begin{array}{l}\mathrm{IC}_{50}^{\mathrm{HepG} 2} \\
(\mu \mathrm{M})\end{array}$ & $\begin{array}{l}\text { Selectivity Index } \\
\mathrm{IC}_{50}{ }_{\mathrm{HepG} 2} / \\
\mathrm{EC}_{50}{ }_{P f 3 \mathrm{D} 7}\end{array}$ \\
\hline $\mathrm{O}_{2} \mathrm{~N}$ & $5.9 \pm 0.7$ & $>25$ & $>4$ \\
\hline$\sum_{N}^{\mathrm{O}_{2} \mathrm{~N}}$ & $8 \pm 2$ & 81 & 10 \\
\hline Artesunate & $0.013 \pm 0.006$ & ------ & ---- \\
\hline
\end{tabular}

Values represent the mean $\pm \mathrm{SD}(n=2)$ 
Table 3 Half-maximal inhibitory concentration $\left(\mathrm{EC}_{50}\right)$ against $P$. falciparum sensitive and resistance strains, resistance index $\left(\mathrm{RI}=\mathrm{EC}_{50}{ }^{\text {resistant/ }}\right.$ $\mathrm{EC}_{50}{ }^{3 \mathrm{D} 7}$ )

\begin{tabular}{lcllllll}
\hline Compound & \multicolumn{2}{l}{$\mathrm{EC}_{50}(\mu \mathrm{M})$ average $\pm \mathrm{SD}$} & & & & \\
\cline { 2 - 8 } & 3D7 & $\mathrm{Dd} 2$ & $\mathrm{RI}$ & $\mathrm{TM} 90 \mathrm{C} 6 \mathrm{~B}$ & $\mathrm{RI}$ & 3D7 $^{\mathrm{R}} \_848$ & $\mathrm{RI}$ \\
\hline 11 & $8 \pm 4$ & $30 \pm 20$ & 3.8 & $31 \pm 8$ & 3.9 & $7 \pm 3$ & 0.9 \\
Artesunate & $0.008 \pm 0.002$ & $0.007 \pm 0.003$ & 0.9 & $0.0069 \pm 0.0006$ & 0.9 & $0.012 \pm 0.006$ & 1.5 \\
Pyrimethamine & $0.045 \pm 0.004$ & $>10$ & $>222$ & - & - & - & - \\
Atovaquone & $0.0008 \pm 0.0002$ & - & - & $>1$ & $>1250$ & - & - \\
MMV692848 & $0.12 \pm 0.02$ & - & - & - & - & $2.4 \pm 0.3$ & 20 \\
\hline
\end{tabular}

and fourfold greater, respectively than the $\mathrm{EC}_{50}$ values against $3 \mathrm{D} 7$ sensitive strain, while the $\mathrm{EC}_{50}$ value against $3 \mathrm{D} 7^{\mathrm{R}} \_848$ strain was similar to the $\mathrm{EC}_{50}$ value against the sensitive strain (Fig. 3). These findings indicate that $\mathbf{1 1}$ has comparable potency against the resistant strains in the panel. Moreover, the RI values varied from 0.9 to 3.9 (Table 3 ), which were considerably smaller than the RI values observed for the standard antimalarials against the resistant strains $(\mathrm{RI}=20->1250)$. These findings suggest no crossresistance between the bis thiazole derivative (11) and the antimalarials pyrimethamine, atovaquone, and MMV692848.

The main molecular target of nitazoxanide in protozoa and anaerobic bacteria is pyruvate:ferredoxin oxidoreductase (PFOR), a biomolecule involved in the enzymedependent electron transfer reaction and essential to the anaerobic energy metabolism, especially, in anaerobic protozoan parasites $[60,61]$. Nevertheless, to the best of our knowledge, no genes encoding PFOR have been isolated from $P$. falciparum, suggesting that the antiplasmodial activity of the nitazoxanide derivatives is via other mechanism of action. In line with this, organisms that lack the PFOR and resistant to metronidazole (a nitroimidazole derivative that targets PFOR catalytic reaction) are sensitive to nitazoxanide and nitazoxanide derivatives [62, 63]. Furthermore, compound $\mathbf{1 1}$ showed comparable potencies against the sensitive and resistant strains of the parasite, indicating that the mechanism of action underlying the antiplasmodial activity is not related to the inhibition of the dihydrofolate reductase (DHFR), cytochrome bc1 complex (cyt $b c 1$ ), and phosphatidylinositol 4-OH kinase (PI4K) enzymes. Therefore, the mechanism of action of $\mathbf{1 1}$ against $P$. falciparum is unknown and shall be investigated.

\section{Conclusion}

Two methodologies were studied to prepare NTz and analogs. The use of triphosgene rendered higher yield than the use of oxyma to obtain the desired amides. All the compounds of A series and all the amide derivatives of 2-aminothiazole-4-carboxylate, which not present nitro group showed poor inhibitory activity against $P$. falciparum

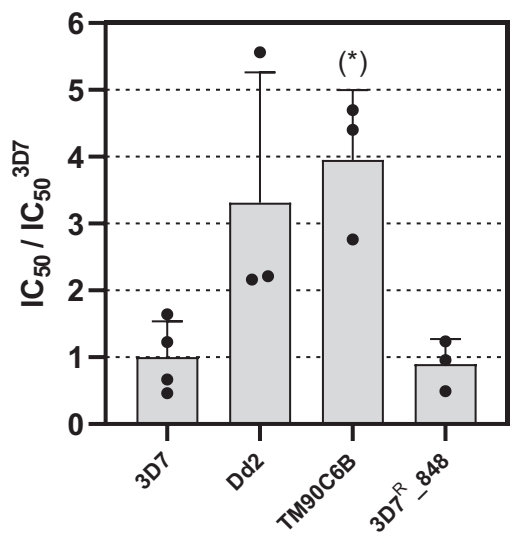

Fig. 3 Half-maximal inhibitory concentration of $\mathbf{1 1}$ against sensitive (3D7) and resistant (Dd2, TM90C6B and 3D7 $\left.7^{\mathrm{R}} \_848\right)$ strains, normalized by the $\mathrm{IC}_{50}$ value against the sensitive strain $\left({ }^{*} P<0.05\right)$

(3D7 strain) at $10 \mu \mathrm{M}$. Ntz showed moderate inhibition with $30 \%$ of growth reduction of parasite at $10 \mu \mathrm{M}$ and Tiz was a poor inhibitor of $P$. falciparum 3D7 strain. As the previous evaluation of $\mathrm{Ntz}$ and Tiz, carried out by NavarreteVazquez et al. [33], was performed against schizonts of the rodent $P$. berghei, our investigations unveiled weak activity for Ntz against the human parasite P. falciparum. However, the bis thiazole analogs (11 and 13), showed attractive inhibitory activity with $\mathrm{EC}_{50}$ values of $5.9 \mu \mathrm{M}$ and $8 \mu \mathrm{M}$, and low propensity to show toxic effect against HepG2 cells. Moreover, the representative compound of the series (11) showed no cross-resistance against a panel of sensitive and resistant parasites. We concluded that the nitro group of $\mathbf{1 1}$ and $\mathbf{1 3}$ play an important role for their bioactivity against the human malaria parasite. Taking into account that the amine derivative $\mathbf{1 6}$ is a poor inhibitor, it could be concluded that the presence of an amide or carbamate in the second thiazole ring, derived from 2-aminothiazole-4-carboxylate, improve the antimalarial activity.

\section{Experimental}

Most of the reagents were purchased from commercial suppliers and used without further purification, some of them were synthetized by part of the group. 
${ }^{1} \mathrm{H}$ and ${ }^{13} \mathrm{C}$ NMR spectra were recorded on Brucker Avance Neo $400 \mathrm{MHz}$ spectrometer using the indicated deuterated solvents and TMS as an internal standard. Chemical shifts $(\delta)$ are given in parts per millon (ppm), multiplicities according to: singlet (s), broad singlet (ba), doublet (d), triplet (t), (doublet of doublets (dd), doublet of triplets (dt), doublet of doublet of doublets (ddd), multiplet (m). Coupling constants $(J)$ are expressed in $\mathrm{Hz}$.

All mass spectra were acquired with a Shimadzu 8040 HPLC-MS-MS equipment, with LC-20AD pumps, a SIL20A autosampler, electrospray ionization and triplequadrupole mass detector. Flash column chromatography was carried out with silica gel 60 (J.T. Baker, $40 \mu \mathrm{m}$ average particle diameter). All reactions and chromatographic separations were monitored by TLC, conducted on 0.25 $\mathrm{mm}$ silica gel plastic sheets (Macherey/Nagel, Polygram_ SIL G/UV 254). TLC plates were analyzed under $254 \mathrm{~nm}$ UV light, iodine vapor, or ninhydrine spray. Yields are reported for chromatographically and spectroscopically $\left({ }^{1} \mathrm{H}\right.$ and ${ }^{13} \mathrm{C} \mathrm{NMR}$ ) pure compounds.

All solvents were purified according to literature procedures [64]. All reactions were carried in dry, freshly distilled solvents under anhydrous conditions unless otherwise stated.

\section{General procedure for amide bond formation using oxyma pure}

Oxyma pure $(1.2 \mathrm{mmol})$, EDCI $(1.2 \mathrm{mmol})$, DIPEA (1.2 mmol), 4-DMAP (catalytic) were added to a stirred solution of the respective acid $(1.2 \mathrm{mmol})$ and amine (1.0 mmol) under $\mathrm{N}_{2}$ atmosphere in dry solvent $\left(\mathrm{CH}_{2} \mathrm{Cl}_{2}\right.$ or $\mathrm{THF})$ at $0{ }^{\circ} \mathrm{C}$. The resulting mixture was stirred at room temperature for $12-48 \mathrm{~h}$ and then evaporated in vacuo. The crude was dissolved in EtOAc, washed with $5 \% \mathrm{v} / \mathrm{v} \mathrm{HCl}$ and with a saturated solution of $\mathrm{NaHCO}_{3}$, dried with $\mathrm{Na}_{2} \mathrm{SO}_{4}$, filtered, and evaporated in vacuo. The crude was purified by flash chromatography using the corresponding eluent to give the amide.

\section{General procedure for amide bond formation using triphosgene}

To a stirred solution of $(1.0 \mathrm{mmol})$ acid, $(0.4 \mathrm{mmol})$ triphosgene were added in dry THF under $\mathrm{N}_{2}$ atmosphere at room temperature. After $10 \mathrm{~min} 2.4 \mathrm{mmol}$ of 2,4,6-colidine were added, and a white precipitate was formed. After $30 \mathrm{~min}, 0.9 \mathrm{mmol}$ of the respective amine and $0.9 \mathrm{mmol}$ of DIPEA were added. The resulting mixture was stirred at reflux for $12-24 \mathrm{~h}$. The mixture is concentrated to dryness and the crude was dissolved in EtOAc, washed with $5 \% \mathrm{v} / \mathrm{v}$ $\mathrm{HCl}$ and a saturated solution of $\mathrm{NaHCO}_{3}$, dried with $\mathrm{Na}_{2} \mathrm{SO}_{4}$, filtered and evaporated in vacuo. The crude was purified by flash chromatography using the corresponding eluent to give the amide.

\section{2-[(5-Nitro-1,3-thiazol-2-yl)carbamoyl]phenyl acetate (1)}

Compound 1 was obtained following the general procedure for in situ acid chloride formation from 6 (236 mg, $1.63 \mathrm{mmol}$ ) and acetylsalicylic acid, in $19 \mathrm{~mL}$ of dry THF. Reaction was refluxed $6 \mathrm{~h}$ and stirred $14 \mathrm{~h}$ at $40-50{ }^{\circ} \mathrm{C}$. Yield $42 \%$. Brown powder. $\mathrm{Rf}=0.35$ using a mixture of $\mathrm{CHCl}_{3}: \mathrm{MeOH}$ (3:0.2) as eluent. ${ }^{1} \mathrm{H}$ NMR $(400 \mathrm{MHz}$, DMSO) $\delta$ (ppm): 13.61 (ba, 1H), 8.68 (s, 1H), 7.87 (dd, $J=7.9,1.6 \mathrm{~Hz}, 1 \mathrm{H}), 7.67(\mathrm{td}, J=7.9,1.7 \mathrm{~Hz}, 1 \mathrm{H}), 7.43(\mathrm{td}$, $J=7.6,1.0 \mathrm{~Hz}, 1 \mathrm{H}), 7.30(\mathrm{dd}, J=8.17,0.9 \mathrm{~Hz}, 1 \mathrm{H}), 2.26$ (s, 3H). ${ }^{13} \mathrm{C}$ NMR (100 MHz, Acetona-d 6 ) $\delta$ (ppm): 168.7, 164.7, 162.3, 151.3, 148.9, 141.4, 133.7, 129.7, 126.1, 124.2, 123.7, 20.0. MS (ESI + ) calcd for $\mathrm{C}_{12} \mathrm{H}_{9} \mathrm{~N}_{3} \mathrm{O}_{5} \mathrm{~S}$, $[\mathrm{M}+\mathrm{H}]^{+}$308.02, found 308.05.

\section{tert-Butyl (4-((5-nitrothiazol-2-yl)carbamoyl)thiazol-2-yl) carbamate (11)}

Compound 11 was obtained following the general procedure for amide bond formation using oxyma pure from 6 (80 $\mathrm{mg}, \quad 0.55 \mathrm{mmol})$ and 2-((tert-butoxycarbonyl)amino) thiazole-4-carboxylic acid in $8 \mathrm{~mL}$ of dry THF. Reaction was refluxed $3 \mathrm{~h}$ and stirred $14 \mathrm{~h}$ at $40-50{ }^{\circ} \mathrm{C}$. Yield $35 \%$. White powder. $\mathrm{R}_{\mathrm{f}}=0.24$ with a mixture of $\mathrm{CHCl}_{3}: \mathrm{MeOH}$ (3:0.1) as eluent. ${ }^{1} \mathrm{H}$ NMR $\left(400 \mathrm{MHz}, \mathrm{CDCl}_{3}\right) \delta$ (ppm): $10.51(\mathrm{~s}, 1 \mathrm{H}), 8.38(\mathrm{~s}, 1 \mathrm{H}), 8.0(\mathrm{~s}, 1 \mathrm{H}), 3.91(\mathrm{~s}, 1 \mathrm{H}), 1.58(\mathrm{~s}$, 9H). ${ }^{13} \mathrm{C} \mathrm{NMR}\left(100 \mathrm{MHz}, \mathrm{CDCl}_{3}\right) \delta(\mathrm{ppm}): 176.4,162.3$, $160.8,160.6,146.4,141.3,141.0,121.8,84.2$, 28.1. MS (ESI -) $m / z$ calcd for $\mathrm{C}_{12} \mathrm{H}_{13} \mathrm{~N}_{5} \mathrm{O}_{5} \mathrm{~S}_{2}[M-\mathrm{H}]^{-} 370.03$, found 370.10 .

\section{SYBR green I growth inhibition assay against $P$. falciparum asexual forms}

Continuous in vitro cultures of $P$. falciparum (strains 3D7, TM90C6B, and $3 \mathrm{D} 7^{\mathrm{R}}$ _848) were kept using an adaptation of the method described by Trager and Jansen [65]. $P$. falciparum cultures were synchronized for assays by treatment with a solution of $5 \%$ sorbitol for $10 \mathrm{~min}$, as described by Lambros and Vanderberg [66]. Compounds were diluted to a stock concentration of $20 \mathrm{mM}$ in $100 \%$ DMSO before the experiments and maintained at $-20{ }^{\circ} \mathrm{C}$. Compound inhibitory potencies were determined using the SYBR Green I phenotypic assay (Smilkstein et al.) [67]. Briefly, in 96-well plates, $180 \mu \mathrm{L}$ of a parasite suspension in the early trophozoite (ring) form at $0.5 \%$ parasitemia and $2 \%$ hematocrit was incubated for $72 \mathrm{~h}$ with $20 \mu \mathrm{L}$ of $10 \times$ concentrated serial dilutions of each compound. The antimalarial artesunate, pyrimethamine, atovaquone, and 
MMV692848 were used as positive controls of inhibition for the cross-resistance experiments. The plates were kept at $37^{\circ} \mathrm{C}$ and in a low oxygen atmosphere $\left(5 \% \mathrm{O}_{2}, 5 \% \mathrm{CO}_{2}\right.$, $90 \% \mathrm{~N}_{2}$ ). Positive and negative growth controls were added to each independent plate. The growth medium was then removed, and the deposited RBCs were resuspended in PBS buffer ( $116 \mathrm{mM} \mathrm{NaCl}, 10 \mathrm{mM} \mathrm{Na}_{2} \mathrm{HPO}_{4}, 3 \mathrm{mM} \mathrm{KH} \mathrm{KH}_{2} \mathrm{PO}_{4}$. A solution of SYBR Green I DNA Stain diluted was added in a lysis buffer $(20 \mathrm{mM}$ Tris, $5 \mathrm{mM}$ EDTA, $0.008 \%(\mathrm{~m} / \mathrm{v})$ saponin, and $0.08 \%(\mathrm{~m} / \mathrm{v})$ Triton $\mathrm{X}-100$, at $\mathrm{pH} 7.5)$ to induce hemolysis. The plates were incubated for an additional $30 \mathrm{~min}$, after which the fluorescence of the plate was measured (absorption and emission wavelengths of $485 \mathrm{~nm}$ and $535 \mathrm{~nm}$, respectively). Fluorescence intensity was analyzed in terms of parasite viability as compared to controls, using the Origin 9.0 software (OriginLab, Northampton, MA, USA). Concentration-response curves were built, and half-maximal inhibitory concentration $\left(\mathrm{IC}_{50}\right)$ values were determined for each compound using nonlinear regression analysis.

\section{Cultivation of human hepatocellular carcinoma cells (HepG2 cell line)}

A culture of HepG2 cells was kept in a flask in a humidified atmosphere of $5 \% \mathrm{CO}_{2}$ at $37{ }^{\circ} \mathrm{C}$. The culture medium used was RPMI 1640 supplemented with $25 \mathrm{mM}$ HEPES (pH 7.4), $24 \mathrm{mM}$ sodium bicarbonate, $11 \mathrm{mM}$ D-glucose, $40 \mu \mathrm{g} /$ $\mathrm{mL}$ penicillin-streptomycin, and $10 \%(\mathrm{v} / \mathrm{v})$ bovine fetal serum. Every 3-4 days, treatment with a $0.25 \%$ trypsin solution was used to release cells from the flask walls and a 1:4 proportion of the cells were maintained in culture.

\section{MTT assay for cytotoxicity evaluation}

An adaptation of the MTT assay described by Denizot and Lang [68] was employed to determine cytotoxic activity. The HepG2 cells were counted and distributed in a 96-well plate, in a proportion of $5 \times 10^{6}$ cells per well. The plate was incubated overnight at $37^{\circ} \mathrm{C}$, in a humidified atmosphere of $5 \% \mathrm{CO}_{2}$. After that, serial dilutions of the compounds were added in a 1:9 proportion to each well, and the plates were incubated for another $24 \mathrm{~h}$. Positive (no compound) controls were added to each plate for normalization of results. The supernatant was then removed, and a solution of MTT salt (3-(4,5-dimethylthiazol-2-yl)-2,5-diphenyltetrazolium bromide) was added to each well. After $2-4 \mathrm{~h}$ of incubation, the formazan crystals formed by MTT reduction were solubilized in DMSO. The absorbance of the plate at $570 \mathrm{~nm}$ was measured, and the intensity values obtained were converted to viability values using the equation below. Dose-response curves were crafted for each compound using the OriginPro 9.0 software (OriginLab), and the minimum inhibitory concentration for $50 \%$ of cells $\left(\mathrm{IC}_{50}{ }^{\mathrm{HepG} 2}\right)$ was determined for each compound. The selectivity index (SI) was calculated by the ratio of $\mathrm{IC}_{50}{ }^{\mathrm{HepG} 2}$ to $\mathrm{IC}_{50}{ }^{3 \mathrm{D} 7}$.

\section{Data availability}

NMR and MS spectra are depicted in the Supplementary Material.

Acknowledgements This work was supported by Grants from CSIC Grupos 2006 (Universidad de la República) and PEDECIBA (Uruguay). We thank the Sao Paulo Research Foundation-FAPESP for funding the research (CEPID grant 2013/07600-3, 2020/12904-5, 2018/07287-7). This study was financed in part by the Coordenação de Aperfeiçoamento de Pessoal de Nível Superior-Brasil (CAPES) Finance Code 001.

\section{Compliance with ethical standards}

Conflict of interest The authors declare no competing interests.

Publisher's note Springer Nature remains neutral with regard to jurisdictional claims in published maps and institutional affiliations.

\section{References}

1. World Health Organization, World Malaria Report 2020, World Health Organization, Geneva, Switzerland. https://apps.who.int/ iris/rest/bitstreams/1321872/retrieve.

2. Zawawi A, Alghanmi M, Alsaady I, Gattan H, Zakai H, Couper K. The impact of COVID-19 pandemic on malaria elimination. Parasite Epidemiol Control. 2020;11:e00187. https://doi.org/10. 1016/j.parepi.2020.e00187.

3. Rogerson SJ, Beeson JG, Laman M, Poespoprodjo JR, William T, Simpson JA, et al. Identifying and combating the impacts of COVID-19 on malaria. BMC Medicine. 2020;18:239. https://doi. org/10.1186/s12916-020-01710-x

4. Sherrard-Smith E, Hogan AB, Hamlet A, Watson OJ, Whittaker $\mathrm{C}$, Winskill $\mathrm{P}$, et al. The potential public health consequences of COVID-19 on malaria in Africa. Nat Med. 2020;26:1411-6. https://doi.org/10.1038/s41591-020-1025-y

5. World Health Organization. The potential impact of health service disruptions on the burden of malaria: a modelling analysis for countries in sub-Saharan Africa. 2020. https://www.who.int/ publications/i/item/9789240004641

6. Dondorp AM, Nosten F, Yi P, Das D, Phyo AP, Tarning J, et al. Artemisinin resistance in Plasmodium falciparum malaria. New Engl J Med. 2009;361:455-67. https://doi.org/10.1056/NEJMoa 0808859

7. Leang R, Taylor WR, Bouth DM, Song L, Tarning J, Char MC, et al. Evidence of Plasmodium falciparum malaria multidrug resistance to artemisinin and piperaquine in western Cambodia: dihydroartemisinin-piperaquine open-label multicenter clinical assessment. Antimicrob Agents Chemother. 2015;59:4719-26. https://doi.org/10.1128/AAC.00835-15

8. Noedl H, Se Y, Schaecher K, Smith BL, Socheat D, Fukuda M. Evidence of artemisinin-resistant malaria in western Cambodia. $\mathrm{N}$ Engl J Med. 2008;359:2619-20. https://doi.org/10.1056/ NEJMc0805011

9. Pushpakom S, Iorio F, Eyers PA, Escott KJ, Hopper S, Wells A, Doig A, Guilliams T, Latimer J, McNamee C, Norris A, Sanseau 
P, Cavalla D, Pirmohamed M. Drug repurposing: progress, challenges and recommendations. Nat Rev Drug Discov. 2019;18:41-58. https://doi.org/10.1038/nrd.2018.168

10. Shanmugam A, Muralidharan N, Velmurugan D, Gromiha MM. Therapeutic targets and computational approaches on drug development for COVID-19. Curr Top Med Chem. 2020;20:2210-20. https://doi.org/10.2174/1568026620666200710105507

11. Chhabria MT, Patel S, Modi P, Brahmkshatriya PK. Thiazole: a review on chemistry, synthesis and therapeutic importance of its derivatives. Curr Top Med Chem. 2016;16:2841-62. https://doi. org/10.2174/1568026616666160506130731.

12. Rossignol JF, Cavier R. New derivatives of 2-benzamido 5nitrothiazoles. United States Patent. 1976;950:351. April 13

13. Cavier R, Rossignol JF. Etude de diverses associations d'anthelminthiques chez la souris. Rev Méd Vét. 1982;133:779-83.

14. Aslam S, Musher DM. Nitazoxanide: clinical studies of a broadspectrum anti-infective agent. Future Microbiol. 2007;2:583-90. https://doi.org/10.2217/17460913.2.6.583

15. Dubreuil L, Houcke I, Mouton Y, Rossignol JF. In vitro evaluation of activities of nitazoxanide and tizoxanide against anaerobes and aerobic organisms. Antimicrob Agents Chemother. 1996;40:2266-70. https://doi.org/10.1128/AAC.40.10.2266

16. Anderson VR, Curran MP. Nitazoxanide: a review of its use in the treatment of gastrointestinal infections. Drugs. 2007;67:1947-67. https://doi.org/10.2165/00003495-200767130-00015

17. Rossignol JF, Kabil SM, El-Gohary Y, Younis AM. Nitazoxanide in the treatment of amoebiasis. Trans R Soc Trop Med Hyg. 2007;101:1025-31. https://doi.org/10.1016/j.trstmh.2007.04.001

18. Chero JC, Saito M, Bustos JA, Blanco EM, Gonzalvez G, García $\mathrm{H}$, et al. Hymenolepis nana infection: symptoms and response to nitazoxanide in field conditions. Trans $\mathrm{R}$ Soc Trop Med Hyg. 2007;101:203-5. https://doi.org/10.1016/j.trstmh.2006.04.004

19. Speich B, Ame SM, Ali SM, Alles R, et al. Efficacy and safety of nitazoxanide, albendazole, and nitazoxanide-albendazole against Trichuris trichiura infection: a randomized controlled trial. PLOS Negl Trop Dis. 2012;6:e1685. https://doi.org/10.1371/journal. pntd.0001685

20. Rossignol JF, El-Gohary M. Nitazoxanide in the treatment of viral gastroenteritis: a randomized double-blind placebo-controlled clinical trial. Aliment Pharmacol Ther. 2006;24:1423-30. https:// doi.org/10.1111/j.1365-2036.2006.03128.x.

21. Rossignol JF, Abou Zekry M, Hussein A, Santoro MG. Effect of nitazoxanide in treating rotavirus diarrhea: a randomized, doubleblind, placebo-controlled trial. Lancet. 2006;368:124-9. https:// doi.org/10.1016/s0140-6736(06)68852-1

22. Siddiq DM, Koo HL, Adachi JA, Viola GM. Norovirus gastroenteritis successfully treated with nitazoxanide. J Infection. 2011;63:394-7. https://doi.org/10.1016/j.jinf.2011.08.002

23. Rossignol JF. Nitazoxanide, a new drug candidate for the treatment of Middle East respiratory syndrome coronavirus. J Infect Public Health. 2016;9:227-30. https://doi.org/10.1016/j.jiph.2016. 04.001

24. Rossignol JF, Elfert A, Keeffe EB. Treatment of chronic hepatitis $\mathrm{C}$ using a 4-week lead-in with nitazoxanide before peginterferon plus nitazoxanide. J Clin Gastroenterol. 2010;44:504-9. https:// doi.org/10.1097/mcg.0b013e3181bf9b15

25. Korba BE, Montero AB, Farrar K, Gaye K, et al. Nitazoxanide, tizoxanide and other thiazolides are potent inhibitors of hepatitis $B$ virus and hepatitis $\mathrm{C}$ virus replication. Antiviral Research. 2008;77:56-63. https://doi.org/10.1016/j.antiviral.2007.08.005

26. Rossignol JF. Nitazoxanide: a first-in-class broad-spectrum antiviral agent. Antiviral Research. 2014;110:94-103. https://doi.org/ 10.1016/j.antiviral.2014.07.014

27. Hoffman PS, Sisson G, Croxen MA, Welch K, et al. Antiparasitic drug nitazoxanide inhibits the pyruvate oxidoreductases of Helicobacter pylori, selected anaerobic bacteria and parasites, and
Campylobacter jejuni. Antimicrobial Agents and Chemotherapy. 2007;51:868-76. https://doi.org/10.1128/aac.01159-06

28. Elazar M, Liu M, McKenna SA, Liu P, et al. The anti-hepatitis c agent nitazoxanide induces phosphorylation of eukaryotic initiation factor $2 \alpha$ via protein kinase activated by double-stranded RNA activation. Gastroenterology. 2009;137:1827-35. https://doi. org/10.1053/j.gastro.2009.07.056

29. Rossignol JF, La Frazia S, Chiappa L, Ciucci A, Santoro MG. Thiazolides, a new class of anti-influenza molecules targeting viral hemagglutinin at the post- translational level. J Biol Chemistry. 2009;284:29798-808. https://doi.org/10.1074/jbc.m109.029470

30. Stachulski AV, Santoro MG, Piacentini S, Belardo G, et al. Second-generation nitazoxanide derivatives: thiazolides are effective inhibitors of the influenza A virus. Future Medicinal Chemistry. 2018;10:851-62. https://doi.org/10.4155/fmc-20170217.

31. Wang M, Cao R, Zhang L, et al. Remdesivir and chloroquine effectively inhibit the recently emerged novel coronavirus (2019$\mathrm{nCoV}$ ) in vitro. Cell Res. 2020;30:269-71. https://doi.org/10. 1038/s41422-020-0282-0.

32. Jasenosky LD, Cadena C, Mire CE, et al. The FDA-approved oral drug nitazoxanide amplifies host antiviral responses and inhibits Ebola virus. iScience. 2019;19:1279-1290. https://doi.org/10. 1016/j.isci.2019.07.003

33. Navarrete-Vazquez G, Chávez-Silva F, Argotte-Ramos R, Rodríguez-Gutiérrez MC, et al. Synthesis of benzologues of nitazoxanide and tizoxanide: a comparative study of their in vitro broad-spectrum antiprotozoal activity. Bioorg Med Chem Lett. 2011;21:3168-71. https://doi.org/10.1016/j.bmcl.2011.02.100

34. Karade HN, Acharya BN, Sathe M, Kaushik MP. Design, synthesis, and antimalarial evaluation of thiazole-derived amino acids. Med Chem Res. 2008;17:19-29. https://doi.org/10.1007/ s00044-008-9089-0

35. Cabrera DG, Douelle F, Feng T-S, et al. Novel orally active antimalarial thiazoles. J Med Chem. 2011;54:7713-9. https://doi. org/10.1021/jm201108k

36. Sharma M, Prasher P. An epigrammatic status of the 'azole'-based antimalarial drugs. RSC Med Chem. 2020;11:184-211. https:// doi.org/10.1039/C9MD00479C

37. Peña S, Scarone L, Medeiros A, Manta E, et al. Synthesis of precursors and macrocycle analogs of aerucyclamides as antitrypanosomal agents. Med Chem Commun. 2012;3:1443-8. https://doi.org/10.1039/C2MD20218B

38. Peña S, Scarone L, Manta E, Serra G. First total synthesis of aerucyclamide B. Tetrahedron Letters. 2013;54:2806-8. https:// doi.org/10.1016/j.tetlet.2013.03.060

39. Peña S, Fagundez C, Medeiros A, Comini M, et al. Synthesis of cyclohexapeptides as antimalarial and anti-trypanosomal agents. Med Chem Commun. 2014;5:1309-16. https://doi.org/10.1039/ C4MD00135D

40. Peña S, Scarone L, Serra G. Macrocycles as potential therapeutic agents in neglected diseases. Future Med Chem. 2015;7:355-82. https://doi.org/10.4155/fmc.14.133

41. Franco J, Medeiros A, Benítez D, Perelmuter K, et al. In vitro activity and mode of action of distamycin analogues against African trypanosomes. Eur J Med Chem. 2017;126:776-88. https://doi.org/10.1016/j.ejmech.2016.12.002

42. Fagundez C, Sellanes D, Serra G. Synthesis of cyclic peptides as potential anti-malarials. ACS Combinatorial Sci. 2018;20:212-9. https://doi.org/10.1021/acscombsci.7b00154

43. Posada L, Serra G. First total synthesis of versicotide D and analogs. Tetrahedron Lett. 2019;60:151281. https://doi.org/10. 1016/j.tetlet.2019.151281

44. Fagundez C, Sellanes D, Peña S, Scarone L, et al. Synthesis, profiling, and in vivo evaluation of cyclopeptides containing $\mathrm{N}$-methyl amino acids as antiplasmodial agents. ACS Med Chem 
Lett. 2019;10:137-41. https://doi.org/10.1021/acsmedchemlett. $8 \mathrm{~b} 00543$

45. Franco J, Scarone L, Comini MA. Novel distamycin analogues that block the cell cycle of African trypanosomes with high selectivity and potency. Eur J Med Chem. 2020;189:112043. https://doi.org/10.1016/j.ejmech.2020.112043

46. Serra G, Posada L, Hojo H. On-resin synthesis of cyclic peptides via tandem $\mathrm{N}$-to-S acyl migration and intramolecular thiol additive-free native chemical ligation. Chem Comm. 2020;56:956-9. https://doi.org/10.1039/C9CC07783A

47. Alvarez N, Velluti F, Guidali F, Serra G, et al. New BI and TRIThiazole copper (II) complexes in the search of new cytotoxic drugs against breast cancer cells. Inorg Chim Acta. 2020;508:119622. https://doi.org/10.1016/j.ica.2020.119622

48. Hohmann K, Mohr R, Hahnke M. Process for preparing an azo compound from a 2-aminothiazole diazo component.United States Patent 4046752. Washington, DC: EE.UU; 1974.

49. Dickey JB, Towne EB, Wright GF. Nitration of 2-aminothiazoles. J Org Chem. 1955;20:499-510. https://doi.org/10.1021/jo01122a013.

50. Odingo J, Bailey MA, Files M, Early JV, et al. In vitro evaluation of novel Nitazoxanide derivatives against Mycobacterium tuberculosis. ACS Omega. 2017;2:5873-90. https://doi.org/10.1021/a csomega.7b00892

51. Gergely M, Kollar L. Aminothiazoles and aminothiadiazoles as nucleophiles in aminocarbonylation of iodobenzene derivatives. Tetrahedron. 2018;74:2030-40. https://doi.org/10.1016/j.tet.2018.03.007

52. Stachulski AV, Pidathala C, Row EC, Sharma R, et al. Thiazolides as novel antiviral agents. 2. Inhibition of hepatitis $\mathrm{C}$ virus replication. J Med Chem. 2011;54:8670-80. https://doi.org/10. 1021/jm201264t

53. Ballard TE, Wang X, Olekhnovich I, Koerner T, et al. Synthesis and antimicrobial evaluation of Nitazoxanide-based analogues: identification of selective and broad spectrum activity. Chem Med Chem. 2010;6:362-77. https://doi.org/10.1002/cmdc.201000475

54. Posada L, Davyt D, Serra G. First total synthesis of versicotide A, B and C. RSC Adv. 2020;10:43653. https://doi.org/10.1039/ D0RA09635K

55. Subirós-Funosas R, Prohens R, Barbas R, et al. Oxyma: an efficient additive for peptide synthesis to replace the benzotriazolebased HOBt and HOAt with a lower risk of explosion. Chem Eur J. 2009;15:9394-403. https://doi.org/10.1002/chem.200900614

56. Smilkstein M, Sriwilaijaroen N, Kelly JX, et al. Simple and inexpensive fluorescence-based technique for high-throughput antimalarial drug screening. Antimicrob Agents Chemother. 2004;48:1803-6. https://doi.org/10.1128/aac.48.5.1803-1806. 2004

57. Gardner MJ, Hall N, Fung E, White O, et al. Genome sequence of the human malaria parasite Plasmodium falciparum. Nature. 2002;419:498-511. https://doi.org/10.1038/nature01097

58. Hall N, Karras M, Raine JD, Carlton JM. et alA comprehensive survey of the Plasmodium life cycle by genomic, transcriptomic, and proteomic analyses. Science. 2005;307:82-86. https://doi.org/ 10.1126/science. 1103717

59. Frech C, Chen N. Genome comparison of human and non-human malaria parasites reveals species subset-specific genes potentially linked to human disease. PLoS Comput Biol. 2011;7:e1002320 https://doi.org/10.1371/journal.pcbi.1002320

60. Anderson VR, Curran MP. Nitazoxanide: a review of its use in the treatment of gastrointestinal infections. Drugs. 2007;67:1947-67. https://doi.org/10.2165/00003495-200767130-00015

61. Wang CC. Validating targets for antiparasite hemotherapy. Parasitology. 1997;114:S31-S44.

62. Fox LM, Saravolatz LD. Nitazoxanide: a new thiazolide antiparasitic agent. Clin Infect Dis. 2005;40:1173-80. https://doi.org/ $10.1086 / 428839$

63. Müller J, Wastling J, Sanderson S, Müller N, Hemphill A. A novel Giardia lamblia nitroreductase, GINR1, interacts with nitazoxanide and other thiazolides. Antimicrob Agents Chemother. 2007;51:1979-86. https://doi.org/10.1128/AAC.01548-06

64. Armarego WLF, Chai C. Purification of laboratory chemicals, sixth edn. Butterworth-Heinemann: Elsevier Inc.; 2009.

65. Trager W, Jensen J. Human malaria parasites in continuous culture. Science. 1976;193:673-5. https://doi.org/10.1126/science. 781840

66. Lambros C, Vanderberg JP. Synchronization of Plasmodium falciparum erythrocytic stages in culture. J Parasitol. 1979;65:418-20.

67. Smilkstein M, Sriwilaijaroen N, Kelly JX, Wilairat P, Riscoe M. Simple and inexpensive fluorescence-based technique for highthroughput antimalarial drug screening. Antimicrob Agents Chemother. 2004;48:1803-6. https://doi.org/10.1128/AAC.48.5.18031806.2004

68. Denizot F, Lang R. Rapid colorimetric assay for cell growth and survival. Modifications to the tetrazolium dye procedure giving improved sensitivity and reliability. J Immunol Methods. 1986;89:271-7. https://doi.org/10.1016/0022-1759 (86)90368-6 